\title{
PRELIMINARY STUDY OF TIME BANKING PARTICIPATION
}

doi: 10.2478/cqpi-2019-0083

Date of submission of the article to the Editor: 04/03/2019

Date of acceptance of the article by the Editor: 17/05/2019

\section{Montalee Sasananan ${ }^{1}$ \\ Khanothai Channarong ${ }^{1}$ \\ Sasikanda Kingnakhonthong ${ }^{1}$ \\ ${ }^{1}$ Thammasat University -Thailand}

Abstract: Thailand will be entering full-scale aging society in 2021, when $20 \%$ of population will be over sixty years old. This will cause significant societal changes, and it is very important that the country is prepared to deal with problems that may arise from aging society. Unfortunately substantial number of senior citizens are financially unprepared for retirement due to low financial literacy. An effective social welfare system is needed, which will require a large amount of financial support. An interesting approach to delivering social welfare is co-production which is a practice that involves public services and communities in the mutual deliveries of welfares. Time banking is an engagement practice which each member agrees to give and take credits for service. Time credits can be earned by providing services to those in need. Such system is a kind of co-production which can help build community relationship and complement social welfare system. Time banking can be applied to all generations, and it is especially suitable for aging society. This paper explores the interests in joining time banking among people living in Bangkok and vicinity. It investigates the respondents' lifestyles, interests in joining time bank, and possible matching of interests. The results reveal existing gaps and may be used in further study for establishing time banking system.

Keywords: Time banking, aging society, community engagement

\section{INTRODUCTION}

Population aging is occurring globally due to lower fertility rates, reduction in mortality due to better health care, and longer life expectancy. Aging population in developing regions are growing faster than in OECD countries. It is predicted that nearly 8 in 10 of the world's older persons will be living in developing countries in 2050 (United Nations, 2017). Countries around the world are attempting to address the financial challenges of population aging. Even though the non-OECD countries with the largest growing elderly generation tend to exhibit more positive financial security behaviors (e.g., China, Hong Kong, Singapore, and Thailand), less than one-third of them report saving for old age (Lyons et. al., 2018). This places great burden on the part of government. 
In Thailand, it is estimated that the health care cost of senior citizens will be $228,482.2$ million baht in 2022, and in 10 years from now it will reach 6-700,000 million baht. (BLA Health Plan, 2018). To financially support this situation, retirement saving system such as social security fund is being prepared to accommodate aging society (TCU 2017). Due to the large amount of financial budgets required for social services, some form of support system will be greatly beneficial. Time banking may provide such complementary support.

Time banking system originated in the United States in the 1980s by an American civil right activist Edgar S. Cahn. In the time banking system, time serves as currency. Time credits are gained by contributing to others and can be used for service required from another person within the system. Time banks are mostly established by local activists or non-governmental organizations (NGO). This research attempts to explore the feasibility of establishing time bank in Thailand by conducting preliminary survey regarding interests in joining time banking among people living in Bangkok and vicinity.

\section{METHODOLOGY}

In order to reduce variation, the research scope is limited to people living in Bangkok and vicinity, which has the population size of 10,831,988 (National Statistics Office, 2017). A questionnaire survey of 400 people living in Bangkok and vicinity was conducted via online and personal interview. The research tool consisted of background data about respondents, questions about satisfaction with social security service, satisfaction with daily living, and involvement in social activities. Areas that the respondents wish to give and take services from time bank were also identified, and matching of interests were performed using mode data.

\section{RESULTS}

This research divided the ages of respondents into 6 groups: less than 18, 18-23, 24$30,31-45,46-59$, and 60 years old or more. In this research 'senior citizens' refer to people over 60 years old, and this is different from the definition given by WHO which defines people over 70 as senior citizens. This is because in Thailand the retirement age in government organization is 60 years old, and 55 in some private organizations. The profile of respondents is shown in Figure 1.1. It can be seen that a majority of respondents (37\%) are between the age of 18-23 years old, and the rest of respondents are equally distributed among other age groups. It was found that $75.78 \%$ of respondents have never heard of time banking system.

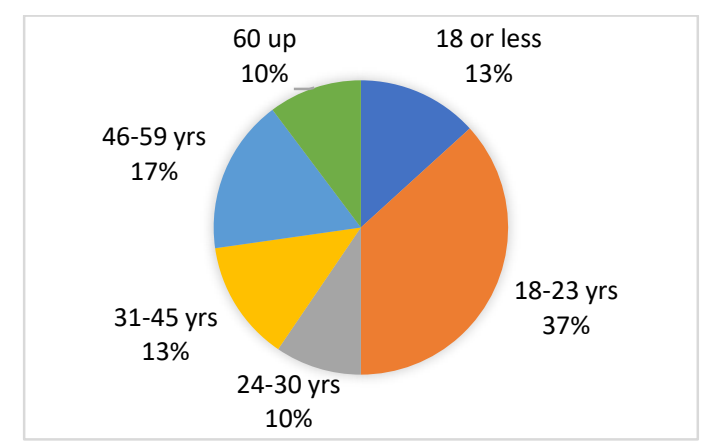

Figure 1.1 Profile of respondents 
The respondents' opinions were evaluated based on Likert's rating scale of 1 to 5 . In interpreting results, the following criteria are used: 4.50-5.00 strongly agree, 3.50-4.49 agree, 2.50-3.49 neutral, 1.50-2.49 disagree, 1.00-1.49 strongly disagree (Best, 1981) When asked about satisfaction with social security service, it was found that on average people of all age groups were moderately satisfied or had neutral feeling toward the government's social security service as shown in Table 1.1. They felt that government should actively promote health knowledge to citizens. In terms of attention that they received from medical personnel, the average respondents felt that they received medium attention during doctor's interview. Even though Thailand's medical care service is known to be among the best in the world, such service is mostly available to wealthy, upper-class people. Generally there is still a lack of medical personnel in government hospitals and people have to wait a long time for medical care.

Table 1.1 Satisfaction with social security service

\begin{tabular}{|l|c|c|c|c|c|c|}
\hline & $\begin{array}{c}\text { Less than } \\
18\end{array}$ & $\begin{array}{c}18- \\
23\end{array}$ & $\begin{array}{c}24- \\
30\end{array}$ & $\begin{array}{c}31- \\
45\end{array}$ & $\begin{array}{c}46- \\
59\end{array}$ & $\begin{array}{c}60 \\
\text { up }\end{array}$ \\
\hline $\begin{array}{l}\text { 1.You feel that the government provides } \\
\text { good social security service. }\end{array}$ & 3.35 & 2.97 & 3.47 & 3.22 & 3.41 & 3.41 \\
\hline $\begin{array}{l}\text { 2.Government should promote health } \\
\text { knowledge to citizens. }\end{array}$ & 3.72 & 3.97 & 3.58 & 3.49 & 3.40 & 3.85 \\
\hline $\begin{array}{l}3 . Y o u \text { feel that medical personnel takes } \\
\text { time to inquire about your health } \\
\text { problems. }\end{array}$ & 3.26 & 3.50 & 3.26 & 3.13 & 3.08 & 3.21 \\
\hline
\end{tabular}

On questions regarding satisfaction with daily living, Table 1.2 reveals that senior citizens were the most satisfied with their roles in family (4.04), as compared with the other groups which were on the high end of moderate satisfaction (3.62-3.88). Most age groups are neutral regarding the question about reliance on close relatives for daily expenses, except for those between 46-59 years old who disagreed. This is not surprising because people of this age are mostly settled and become financially independent.

Most age groups felt that family members helped them out when needed, with particular emphasis found in the younger generations between 18-30 years old who strongly agreed to this question. This reflects close and positive relationship in Thai families. When feeling down, the younger generations who are less than 30 years old tended to consult with family and friends, while the other groups turned to family and friends at a medium level.

Table 1.2 Satisfaction with daily living

\begin{tabular}{|l|c|c|c|c|c|c|}
\hline & $\begin{array}{c}\text { Less than } \\
18\end{array}$ & $\begin{array}{c}18- \\
23\end{array}$ & $\begin{array}{c}24- \\
30\end{array}$ & $\begin{array}{c}31- \\
45\end{array}$ & $\begin{array}{c}46- \\
59\end{array}$ & $\begin{array}{c}60 \\
\text { up }\end{array}$ \\
\hline $\begin{array}{l}\text { 4. You are satisfied with your family roles } \\
\text { e.g. doing household chores, raising } \\
\text { kids, taking care of elderly. }\end{array}$ & 3.62 & 3.81 & 3.73 & 3.62 & 3.88 & 4.04 \\
\hline $\begin{array}{l}\text { 5. Close relatives give you pocket money } \\
\text { for daily expenses. }\end{array}$ & 3.51 & 3.34 & 3.60 & 2.94 & 2.29 & 3.00 \\
\hline $\begin{array}{l}\text { 6. Family members help you when } \\
\text { needed. }\end{array}$ & 4.00 & 4.42 & 4.23 & 3.50 & 3.61 & 4.04 \\
\hline
\end{tabular}




\begin{tabular}{l}
$\begin{array}{l}\text { 7. When feeling down, you consult family } \\
\text { and friends. }\end{array}$ \\
\hline
\end{tabular}

In terms of social involvement, Table 1.3 summarizes the findings in three areas. All age groups agreed that they spent holiday time with their family even though it was not on the strong scale. They were neutral regarding spending free time doing leisure activities with other people in the community. They were also neutral toward joining community events such as new year party, merit making ceremony. This may be due to the fact that the target population for this study are those living in urban areas so they tend to be more individualistic rather than group-oriented. The fact that they seemed to be indifferent in community engagement may indicate some difficulties in setting up time bank in urban areas in the future.

Table 1.3 Social involvement

\begin{tabular}{|l|c|c|c|c|c|c|}
\hline & $\begin{array}{c}\text { Less than } \\
18\end{array}$ & $\begin{array}{c}18- \\
23\end{array}$ & $\begin{array}{c}24- \\
30\end{array}$ & $\begin{array}{c}31- \\
45\end{array}$ & $\begin{array}{c}46- \\
59\end{array}$ & $\begin{array}{c}60 \\
\text { up }\end{array}$ \\
\hline $\begin{array}{l}\text { 8. You spend holiday time with your } \\
\text { family. }\end{array}$ & 3.80 & 3.97 & 3.94 & 3.90 & 3.61 & 3.85 \\
\hline $\begin{array}{l}\text { 9. During free time, you engage in leisure } \\
\text { activities with others, e.g. dancing, } \\
\text { singing, partying. }\end{array}$ & 2.80 & 3.31 & 3.26 & 2.64 & 2.64 & 2.63 \\
\hline $\begin{array}{l}\text { 10. You join community events, e.g. new } \\
\text { year party, merit making ceremony }\end{array}$ & 2.74 & 3.04 & 3.13 & 3.15 & 2.86 & 3.04 \\
\hline
\end{tabular}

As for the interests in joining time bank, the results are illustrated in Table 1.4. The findings reveal that more than half of respondents in all age groups, except those over 60 , expressed interests in being members of time bank. Greatest interests were found among the younger generation at the age between $18-23$ years old $(71 \%)$. This may be explained by the fact that they are not financially obligated to help others in the family. They may have more freedom to explore new things and contribute to others. Based on this findings they can be the target group of time bank if it is to be established in the future. It should be noted that only one-third of senior citizens were interested in becoming time bank members. This is surprising because it was initially speculated that senior citizens would wish to contribute to time bank since they had more free time. The rationale behind this finding may be attributed to the facts that senior citizens may feel that they are not in their best health. They may have some limitations going outside. They may have limited abilities in carrying out some of the listed activities.

To perform matching of interests, respondents were asked in what areas they wished to receive and offer services if they participated in the time banking system. The options were analyzed using modes to indicate the areas of interests. It was found that there were matches between receiving and offering services in the following areas: cleaning air conditioners, helping with household chores, mowing lawn, lifting heavy objects, escort to physical exercises, and escort to doctor visits. Little interests were found in babysitting, both on the giving and receiving ends. There was a common interest among young adults (18-30 years) in offering to tutor school children. This is not surprising because most people in this age groups have just completed their education so they may feel confident in tutoring younger children. However, there is little interests in receiving tutoring services for school children 
Table 1.4 Interests in joining time bank

\begin{tabular}{|l|c|c|c|c|c|c|c|c|c|c|c|c|}
\hline & \multicolumn{2}{|c|}{$\begin{array}{c}\text { Less than } \\
18\end{array}$} & \multicolumn{2}{|c|}{$18-23$} & \multicolumn{2}{|c|}{$24-30$} & \multicolumn{2}{|c|}{$31-45$} & \multicolumn{2}{|c|}{$46-59$} & \multicolumn{2}{c|}{60 up } \\
\hline $\begin{array}{l}\text { Interested in } \\
\text { joining time } \\
\text { bank? }\end{array}$ & Yes & No & Yes & No & Yes & No & Yes & No & Yes & No & Yes & No \\
\hline$\%$ & 58 & 42 & 71 & 29 & 54 & 46 & 66 & 34 & 63 & 37 & 34 & 66 \\
\hline
\end{tabular}

\section{CONCLUSION}

This research is based on the idea of exploring the possibility of setting up a time bank in the city. It investigates the interests in joining a time bank and the potential areas of services. The findings reveal that more than half of the respondents expressed interests in becoming members of time bank, with greatest interests in young generation (between 18-23 years old). There also existed some overlapping areas of services that members can contribute. Thus it is possible to set up time bank in Bangkok and vicinity. However, there may be some obstacles in the actual practice since this study reveals only moderate level of social engagement among the respondents.

The findings of this study is limited to the context of Thailand urban areas only. Other regions or countries may have different findings due to different contexts. For example, people in the rural areas of Thailand may have more collectivism characteristics so they tend to help each other regardless of time bank mechanism. The time bank system may not work effectively in countries where people are dynamics in living. For example, people in Singapore tend to move upscale so they do not stay in one place for a long duration. Time bank tends to flourish in community settings so it may not be effective in such case.

\section{REFERENCE}

Best, J.W., 1981. Research in Education, $4^{\text {th }}$ Ed. Prentice-Hall, New Jersey.

BLA Health Plan, Forecasting of Health Care Costs in the Next 12 Years. http://www.bangkoklife.com/healthplan/th/knowledge/detail/1?pno=2 Retrieved on 7 October 2018

Department of Economic and Social Affairs, Population Division, United Nations. 2017. https://population.un.org/wpp/ Retrieved on 25 November 2018

Lyons, A.C., Grable, J.E., and Joo, S., 2018. A cross-country analysis of population aging and financial security, The Journal of the Economics of Ageing, 12, 96-117.

(National Statistics Office. 2017). http://www2.nso.go.th/ Retrieved on 15 November, 2018

TCU, 2017. Costs of care for elderly persons skyrocket, TCIJ newspaper. https://www.tcijthai.com/news/2017/11/scoop/7501) Retrieved on 15 November, 2018 